\title{
Behavioral Effects of Gangliosides: Anatomical Considerations
}

\author{
Dwaine F. Emerich \\ Cellular Transplants, Inc., \\ Four Richmond Square, Providence, RI 02906
}

\begin{abstract}
Gangliosides are endogenous sialic acid containing glycospingolipids which are highly concentrated in the central nervous system. Although they were first characterized over $\mathbf{4 0}$ years ago, the function(s) played by this unique class of lipids remain largely unknown. Gangliosides have been suggested to play a prominent role in both normal and abnormal developmental processes. In addition, several lines of convergent evidence have indicated that gangliosides exert pronounced trophic effects following damage to peripheral and central nerves. Gangliosides have been shown to (1) enhance cell survival and outgrowth in cultured and developing neurons; (2) promote the regeneration of damaged peripheral and central nerves, and (3) facilitate behavioral recovery by altering the pattern, extent and persistence of the biochemical, morphological and behavioral changes induced by neural trauma. Little is known, however, concerning the neurobiological mechanisms which subserve the behavioral protection afforded by ganglioside treatment. This review focuses on the evidence suggesting that gangliosides mediate functional recovery by minimizing primary or secondary cell loss or promoting the regeneration or sprouting of damaged central nerves subsequent to injury. An understanding of the mechanisms by which gangliosides produce their effects may lead to
\end{abstract}

\footnotetext{
Reprint address:

Dr. Dwaine F. Emerich

Cellular Transplants, Inc.

Four Richmond Square

Providence, RI 02906

USA
}

the development of more efficacious and rational primary or adjunct pharmacological treatments for central nervous system disorders.

\section{KEY WORDS}

gangliosides, recovery of function, sprouting, trophic factors, regeneration.

\section{INTRODUCTION}

One of the major goals of neuroscience is to understand and treat brain disorders. Despite technical and conceptual advances in the neurosciences we still face fundamental questions in neurology. Among the most problematic neurological disorders are those associated with the degeneration of brain neurons. Neurodegenerative diseases, strokes and penetrating wounds all produce unique constellations of behavioral symptoms that result from the destruction of specific neuronal populations. Although research is beginning to reveal the pathophysiology and molecular biology of these disorders there remains a wide gap between our understanding of the substrates of these diseases and our ability to prevent or treat them.

Traditional approaches to the treatment of acute and more chronic neurological disorders typically produce very limited functional recovery and may even produce deleterious side effects. Even in cases where some degree of functional recovery occurs, residual deficits typically continue to compromise the individuals' quality of life $/ 51 /$. Based on the limited efficacy of current treatment modalities it is imperative to develop treatments which limit the extent and 
DWAINE F. EMERICH

persistence of neural trauma and promote functional recovery.

Gangliosides are sialic acid containing glycospingolipids which are highly concentrated in neuronal membranes $/ 40,45,65,66 /$. These large, complex lipids are typically associated with the outer surface of the neuronal membrane and consist of a hydrophobic spingosine and steric acid complex inserted into the neuronal membrane and a hydrophilic component containing sialic acid residues and a variety of carbohydrates which protrude towards the extracellular fluid. Although over 70 different forms of gangliosides /96/ have been identified, most investigators have focused on the monosialoganglioside GM1 because of its demonstrated in vivo and in vitro efficacy as a trophic agent.

The location of gangliosides on the outer portion of the neuronal membrane has led to the speculation that these molecules play a role in cell surface events such as cell to cell recognition, synaptic transmission and receptor-ligand functions. Morphological, developmental, biochemical and behavioral studies have shown that gangliosides participate in a variety of neurobiological functions related to the maturation and repair of neural tissue. For example, there are pronounced changes in ganglioside concentrations and distribution during synaptogenesis and central nervous system (CNS) maturation $/ 29,59 \%$. In addition, developmental disorders which result from impairments in the metabolism of gangliosides (e.g., Tay Sachs disease) are characterized by anomalous patterns of neuronal differentiation and synaptogenesis as well as progressive cognitive deterioration /85,86/. Moreover, administration of antibodies to GM1 ganglioside to developing animals produces permanent alterations in the extent of synaptogenesis and myelination of nervous tissue together with deficits in learning performance $159 \%$. In contrast, exogenously administered gangliosides increase cell survival and enhance neurite outgrowth when added to cultures of developing neurons /12,26,28,38,73/, promote regeneration of damaged central and peripheral nerves $/ 4,43-45 /$, and facilitate behavioral recovery by altering the pattern, extent and persistence of the biochemical, morphological and behavioral changes induced by neural trauma $\quad / 16,17,20,30,32,34,35,37,82,83,89,92-97$, $115,120 \%$. Based upon these observations it has been proposed that gangliosides may serve as useful pharmacological agents for augmenting the plasticity of the CNS and promoting functional recovery. Results such as those described above, coupled with the practical considerations that gangliosides are capable of crossing the blood-brain barrier $/ 64,81,111 /$ and produce no overt toxic side effects $/ 52 /$, make gangliosides particularly attractive neurotrophic agents for the treatment of CNS injury. Although several studies have documented the efficacy of gangliosides in a variety of animal models and human conditions, the mechanism by which gangliosides exert their beneficial effects has remained elusive (see Table 1). The purpose of this article is to review the possible anatomical mechanisms by which gangliosides might produce behavioral recovery in various models of CNS injury.

\section{EFFECTS OF GANGLIOSIDES ON DEVELOPMENT AND PERIPHERAL NERVOUS SYSTEM REGENERATION}

The expression of gangliosides correlates with the development of the CNS and has led to the suggestion that gangliosides play a role in normal neuronal growth. Willinger /117/ reported that the expression of ganglioside GM1 was markedly increased on the neuronal membrane of differentiating cells. Moreover, Rosner /91/ demonstrated that increases in the concentrations of a variety of endogenous gangliosides paralleled cell migration and neuronal differentiation in the optic lobes of the chicken. The differential alterations in ganglioside concentrations during development do not provide direct evidence for a causative role in specific developmental phenomena. However, the abnormal neuronal development associated with disorders of ganglioside metabolism does suggest a direct modulatory role for gangliosides in neuronal growth. GM1 gangliosidosis results from a deficiency of the enzyme $\beta$-galactosidase which is responsible for the degradation of GM1. As a 
TABLE 1

EFFECTS OF GANGLIOSIDES ON BEHAVIORAL AND NEUROBIOLOGICAL RECOVERY FOLLOWING CNS LESIONS

\begin{tabular}{|c|c|c|c|c|}
\hline $\begin{array}{l}\text { Species/ } \\
\text { Lesion }\end{array}$ & $\begin{array}{l}\text { Ganglioside } \\
\text { Treatment }\end{array}$ & $\begin{array}{l}\text { Anatomical/ } \\
\text { Neurochemical } \\
\text { Results }\end{array}$ & $\begin{array}{l}\text { Behavioral } \\
\text { Results }\end{array}$ & Ref \\
\hline $\begin{array}{l}\text { Rat peroneal } \\
\text { nerve }\end{array}$ & $\begin{array}{l}\text { Mix of GM1, GDla, } \\
\text { GDlb, and GT1 } \\
(50 \mathrm{mg} / \mathrm{kg}, \mathrm{IP})\end{array}$ & & $\begin{array}{l}\text { Enhanced neuromuscular } \\
\text { control }\end{array}$ & 13 \\
\hline $\begin{array}{l}\text { Rat sciatic } \\
\text { nerve }\end{array}$ & $\begin{array}{l}\text { Mix of GM1, GD1a, } \\
\text { GDlb, and GT1 } \\
(5 \mathrm{mg} / \mathrm{kg}, \mathrm{IP})\end{array}$ & $\begin{array}{l}\text { Sprouting of moto- } \\
\text { neurons }\end{array}$ & & 44 \\
\hline $\begin{array}{l}\text { Rat fourth } \\
\text { lumbar root }\end{array}$ & $\begin{array}{l}\text { Mix from bovine } \\
\text { brain ( } 50 \mathrm{mg} / \mathrm{kg}, \mathrm{IP})\end{array}$ & & $\begin{array}{l}\text { Enhanced isometric } \\
\text { tension of plantaris } \\
\text { muscle }\end{array}$ & 102 \\
\hline $\begin{array}{l}\text { Rat sciatic } \\
\text { nerve; alloxan- } \\
\text { induced diabetes }\end{array}$ & $\begin{array}{l}\text { Mix of GM1, GD1a, } \\
\text { GD1b and GT1b } \\
(10 \mathrm{mg} / \mathrm{kg}, \mathrm{IP})\end{array}$ & & $\begin{array}{l}\text { Ameliorated loss of } \\
\text { axonal transport }\end{array}$ & 70 \\
\hline $\begin{array}{l}\text { Rat sciatic } \\
\text { nerve; diabetic } \\
\text { peripheral neuro- } \\
\text { pathy }\end{array}$ & $\begin{array}{l}\text { Mix of GM1, GD1a, } \\
\text { GD1b, and GT1b } \\
(20 \mathrm{mg} / \mathrm{kg}, \mathrm{SC})\end{array}$ & $\begin{array}{l}\text { Improvement of nerve } \\
\text { conduction }\end{array}$ & & 108 \\
\hline $\begin{array}{l}\text { Rat; vinblastine- } \\
\text { induced sym- } \\
\text { pathectomy }\end{array}$ & $\begin{array}{l}\text { GM1 and/or NGF } \\
(30 \text { and } 1 \mathrm{mg} / \mathrm{kg}, \mathrm{SC})\end{array}$ & Reduced NE loss & & 117 \\
\hline $\begin{array}{l}\text { Rat ventro- } \\
\text { medial septal } \\
\text { nucleus }\end{array}$ & $\begin{array}{l}\text { Mix of GM1, GD1a, } \\
\text { GD1b, and GT1 } \\
(50 \mathrm{mg} / \mathrm{kg}, \mathrm{IP})\end{array}$ & $\begin{array}{l}\text { Promoted recovery of } \\
\text { ChAT and AChE }\end{array}$ & & 124 \\
\hline $\begin{array}{l}\text { Rat septal } \\
\text { nucleus }\end{array}$ & GM1 (30 mg/kg, IP) & & Decreased emotionality & 84 \\
\hline $\begin{array}{l}\text { Rat dorsal } \\
\text { hippocampus }\end{array}$ & GM1 (30 mg/kg, IM) & \multicolumn{2}{|l|}{$\begin{array}{l}\text { Enhanced recovery of AChE, } \\
\text { ChAT and 5-HT }\end{array}$} & 46 \\
\hline $\begin{array}{l}\text { Rat dorsal } \\
\text { hippocampus }\end{array}$ & GM1 (30 mg/kg, IP) & Enhanced 5-HT uptake & & 61 \\
\hline $\begin{array}{l}\text { Rat hippo- } \\
\text { campus/ } \\
\text { neocortex }\end{array}$ & GM1 (30 mg/kg, IP) & Enhanced ChAT activity & & 104 \\
\hline $\begin{array}{l}\text { Rat entorhinal } \\
\text { cortex }\end{array}$ & $\begin{array}{l}\text { Mix from bovine } \\
\text { brain }(50 \mathrm{mg} / \mathrm{kg}, \mathrm{IM})\end{array}$ & & $\begin{array}{l}\text { Promoted recovery of } \\
\text { T- maze altemation }\end{array}$ & 57 \\
\hline
\end{tabular}


DWAINE F. EMERICH

Table 1 (cont.)

\begin{tabular}{|c|c|c|c|c|}
\hline $\begin{array}{l}\text { Species/ } \\
\text { Lesion }\end{array}$ & $\begin{array}{l}\text { Ganglioside } \\
\text { Treatment }\end{array}$ & $\begin{array}{l}\text { Anatomical/ } \\
\text { Neurochemical } \\
\text { Results }\end{array}$ & $\begin{array}{l}\text { Behavioral } \\
\text { Results }\end{array}$ & Ref \\
\hline $\begin{array}{l}\text { Rat entorhinal } \\
\text { cortex }\end{array}$ & $\begin{array}{l}\text { Mix of GM1, GD1a, } \\
\text { GDlb, and GT1 } \\
(30 \mathrm{mg} / \mathrm{kg}, \mathrm{IM})\end{array}$ & Decreased sprouting & Reduced hyperactivity & 36 \\
\hline $\begin{array}{l}\text { Rat dentate } \\
\text { gyrus }\end{array}$ & GM1 (30 mg/kg, IP) & No reduction of cell loss & $\begin{array}{l}\text { Promoted recovery of } \\
\text { hyperactivity and pharm- } \\
\text { acological sensitivity }\end{array}$ & 120 \\
\hline $\begin{array}{l}\text { Rat dentate } \\
\text { gyrus }\end{array}$ & GM1 (30 mg/kg, IP) & No reduction of cell loss & $\begin{array}{l}\text { Increased ODC activity } \\
\text { on contralateral side }\end{array}$ & 119 \\
\hline $\begin{array}{l}\text { Rat dentate } \\
\text { gyrus }\end{array}$ & $\begin{array}{l}\text { GM1 or } A G F 2 \\
(15 \text { and } 10 \mathrm{mg} / \mathrm{kg} \mathrm{IP})\end{array}$ & No reduction of cell loss & $\begin{array}{l}\text { Induced recovery of } \mathrm{T} \text { - } \\
\text { maze performance }\end{array}$ & 32 \\
\hline $\begin{array}{l}\text { Rat hippo- } \\
\text { campus }\end{array}$ & GM1 (15 mg/kg, IP) & $\begin{array}{l}\text { Prevent loss of ChAT and } \\
\text { HAChU }\end{array}$ & & 27 \\
\hline $\begin{array}{l}\text { Rat nucleus } \\
\text { basalis }\end{array}$ & GM1 (30 mg/kg, IP) & $\begin{array}{l}\text { Prevent cholinergic cell } \\
\text { loss }\end{array}$ & & 20 \\
\hline $\begin{array}{l}\text { Rat nucleus } \\
\text { basalis }\end{array}$ & GM1 (5 mg/kg, ICV) & Prevent decrease in ChAT $\mathrm{F}$ & $\begin{array}{l}\text { Promoted recovery of } \\
\text { passive avoidance and } \\
\text { water maze performance }\end{array}$ & 31 \\
\hline $\begin{array}{l}\text { Rat septal } \\
\text { nucleus }\end{array}$ & AGF2, (10 mg/kg, IP) & $\begin{array}{l}\text { Induce recovery of } \\
\text { ChAT }\end{array}$ & $\begin{array}{l}\text { Partial recovery of radial } \\
\text { arm maze task }\end{array}$ & 34 \\
\hline $\begin{array}{l}\text { Rat septal } \\
\text { nucleus }\end{array}$ & AGF2 (10 mg/kg, IP) & $\begin{array}{l}\text { Prevent loss of ChAT } \\
\text { and HAChU }\end{array}$ & $\begin{array}{l}\text { Prevented hyperactivity } \\
\text { and cognitive deficits }\end{array}$ & 35 \\
\hline $\begin{array}{l}\text { Rat nucleus } \\
\text { basalis }\end{array}$ & GM1 (10 mg/kg, IM) & $\begin{array}{l}\text { Reduced loss of AChE } \\
\text { and ChAT }\end{array}$ & Reduced mortality & 69 \\
\hline Rat striatum & $\begin{array}{l}\text { GM1 }(10,30, \text { or } 50 \\
\mathrm{mg} / \mathrm{kg}, \mathrm{IP})\end{array}$ & $\begin{array}{l}\text { Reduced loss of ChAT } \\
\text { and GAD }\end{array}$ & & 68 \\
\hline Rat striatum & GM1 (30 mg/kg, IP) & $\begin{array}{l}\text { Reduced anterograde } \\
\text { cell loss }\end{array}$ & & 97 \\
\hline Rat striatum & $\begin{array}{l}\text { GM1 or AGF2 } \\
(30 \mathrm{mg} / \mathrm{kg} \mathrm{IP})\end{array}$ & $\begin{array}{l}\text { Regeneration of nigro- } \\
\text { striatal DA system }\end{array}$ & & 4 \\
\hline $\begin{array}{l}\text { Rat substantia } \\
\text { nigra }\end{array}$ & GM1 (30 mg/kg, IP) & \multicolumn{2}{|l|}{ Reduced retrograde cell loss } & 116 \\
\hline $\begin{array}{l}\text { Rat nigrostriatal } \\
\text { pathway }\end{array}$ & GM1 (30 mg/kg, IP) & & $\begin{array}{l}\text { Reduced rotational beh- } \\
\text { avior }\end{array}$ & 94 \\
\hline $\begin{array}{l}\text { Rat nigrostriatal } \\
\text { pathway }\end{array}$ & $\begin{array}{l}\text { GM1 or AGF2 } \\
(30 \mathrm{mg} / \mathrm{kg}, \mathrm{IP})\end{array}$ & Induced recovery of $\mathrm{TH}$ & $\begin{array}{l}\text { Reduced rotational beh- } \\
\text { avior }\end{array}$ & 115 \\
\hline Rat striatum & GM1 (30 mg/kg, IP) & & $\begin{array}{l}\text { Promoted recovery of } \\
\text { cognitive behavior }\end{array}$ & 93 \\
\hline
\end{tabular}

cont. 
Table 1 (cont.)

\begin{tabular}{|c|c|c|c|c|}
\hline $\begin{array}{l}\text { Species/ } \\
\text { Lesion }\end{array}$ & $\begin{array}{l}\text { Ganglioside } \\
\text { Treatment }\end{array}$ & $\begin{array}{l}\text { Anatomical/ } \\
\text { Neurochemical } \\
\text { Results }\end{array}$ & $\begin{array}{l}\text { Behavioral } \\
\text { Results }\end{array}$ & Ref \\
\hline $\begin{array}{l}\text { Rat cerebral } \\
\text { cortex }\end{array}$ & GMl (30 mg/kg, IP) & $\begin{array}{l}\text { Induced regrowth of NE } \\
\text { terminals }\end{array}$ & & 62 \\
\hline $\begin{array}{l}\text { Mouse sciatic } \\
\text { nerve; diabetic } \\
\text { peripheral neuro- } \\
\text { pethy }\end{array}$ & $\begin{array}{l}\text { Mix of GM1, GD1a, } \\
\text { GD1b, GT1 } \\
(1 \text { or } 10 \mathrm{mg} / \mathrm{kg}, \mathrm{IP})\end{array}$ & $\begin{array}{l}\text { Promoted recovery of } \\
\text { axonal flow }\end{array}$ & & 76 \\
\hline $\begin{array}{l}\text { Mouse periph- } \\
\text { eral neuropathy }\end{array}$ & $\begin{array}{l}\text { Mix of GM1, GD1a, } \\
\text { GD1b, GT1 } \\
(20 \mathrm{mg} / \mathrm{kg}, \mathrm{SC})\end{array}$ & Induced fiber sprouting & & 109 \\
\hline $\begin{array}{l}\text { Mouse sub- } \\
\text { stantia nigra } \\
\text { (MPTP) }\end{array}$ & $\begin{array}{l}\text { GM1 or AGF2 } \\
(30 \text { or } 10 \mathrm{mg} / \mathrm{kg}, \mathrm{IP})\end{array}$ & $\begin{array}{l}\text { Produced recovery of DA } \\
\text { DOPAC }\end{array}$ & & 47 \\
\hline $\begin{array}{l}\text { Mouse sub- } \\
\text { stantia nigra } \\
\text { (MPTP) }\end{array}$ & GM1 (30 mg/kg, IP) & & $\begin{array}{l}\text { Eliminated haloperidol } \\
\text { induced sensorimotor } \\
\text { effects }\end{array}$ & 121 \\
\hline $\begin{array}{l}\text { Hamster sup- } \\
\text { erior colliculus }\end{array}$ & GM1 (30 mg/kg, IP) & $\begin{array}{l}\text { Enhanced sprouting of } \\
\text { retinotectal fibers }\end{array}$ & & 98 \\
\hline Human stroke & GM1 (20 mg, IM) & & $\begin{array}{l}\text { Produced neurological } \\
\text { improvement }\end{array}$ & 7 \\
\hline $\begin{array}{l}\text { Human cerebro- } \\
\text { vascular disease }\end{array}$ & GM1 (40 mg, IM) & & $\begin{array}{l}\text { Enhanced neurophysio- } \\
\text { logical and clinical } \\
\text { recovery }\end{array}$ & 8 \\
\hline $\begin{array}{l}\text { Human diabetic } \\
\text { neuropathy }\end{array}$ & $\begin{array}{l}\text { Mix of GM1, GD1a, } \\
\text { GD1b, GT1b } \\
(40 \mathrm{mg}, \mathrm{IM})\end{array}$ & & $\begin{array}{l}\text { Produced recovery of sen- } \\
\text { sory perception of lower } \\
\text { extremeties }\end{array}$ & 53 \\
\hline $\begin{array}{l}\text { Human idio- } \\
\text { pathic facial } \\
\text { paralysis }\end{array}$ & $\begin{array}{l}\text { Mix of GM1, GD1a, } \\
\text { GD1b, GT1b } \\
(20 \mathrm{mg}, \mathrm{IM})\end{array}$ & & Complete recovery & 54 \\
\hline $\begin{array}{l}\text { Human } \\
\text { Alzheimer's } \\
\text { disease }\end{array}$ & GM1 (100 mg, IM) & & $\begin{array}{l}\text { No improvement on cog- } \\
\text { nitive or psychosocial } \\
\text { indices }\end{array}$ & 3 \\
\hline $\begin{array}{l}\text { Human } \\
\text { retinitis } \\
\text { pigmintosa }\end{array}$ & $\begin{array}{l}\text { Mix of GM1, GD1a } \\
\text { GD1b, GT1b } \\
(40 \mathrm{mg}, \mathrm{IM})\end{array}$ & & $\begin{array}{l}\text { Improved visual field } \\
\text { area and electroretino- } \\
\text { graphic responses }\end{array}$ & 72 \\
\hline
\end{tabular}


result of this deficiency, meganeurites, characterized by multiple neuritic processes, neurites, and spines develop throughout the nervous system $/ 85,86 /$. Since this pattern of cell growth is typically observed only during early stages of development, these results indicate that an abnormal accumulation of gangliosides has a direct influence on the subsequent growth of neurons.

Numerous in vitro experiments have demonstrated that exogenous gangliosides alter the morphological characteristics of cultured neurons $/ 12,26,28,38,73,125 /$. Gangliosides promote neuritogenesis in a variety of cell lines, with certain cells responding only to specific species of gangliosides. For instance, Carine et al. /15/ reported that GM1, but not GD1a, enhanced neuritogenesis in S20Y murine neuroblastoma cells. Similarly, the selectivity of afferent connections in tetrodotoxin-treated spinal cord explants is dependent on the species of gangliosides used /6/. Mixed bovine ganglioside treatments produced a selective afferent connectivity in these culture preparations while GM1 alone produced a nonselective connectivity. These studies indicated that the exogenous addition of gangliosides enhances the outgrowth of cultured neurons but that this outgrowth is dependent on the molecular form of the ganglioside used. Since the distribution of gangliosides in the nervous system is variable, it is conceivable that gangliosides normally play a role in mediating specific forms of neuronal connectivity and that the extent of functional recovery afforded by gangliosides is a function of precise and subtle anatomical changes.

Ceccarelli and colleagues /18/ initially reported that the exogenous administration of gangliosides promoted sprouting in the peripheral nervous system (PNS). Following a pre- and postganglionic anastomosis of the superior cervical ganglion in cats, daily administration of gangliosides resulted in a complete recovery from paralysis together with normal pupillary and nictitating membrane function. Since animals typically exhibit a partial recovery from this surgery as a result of regenerating axons reinnervating the cervical ganglion it was concluded that the gangliosides had promoted the regeneration of the axotomized fibers. Support for the assumption of regeneration came from visualization of increased catecholaminergic histofluorescence in the cervical ganglion following the anastomosis. Since these initial studies, several laboratories have confirmed that gangliosides promote the regeneration and sprouting of damaged peripheral nerves and muscle $/ 13,44,45,56,60 /$.

\section{GANGLIOSIDE-INDUCED REGENERATION AND SPROUTING FOLLOWING NEURAL INJURY}

\section{Septohippocampal cholinergic system}

Given that gangliosides could markedly potentiate the regenerative response of peripheral nerves, Oderfeld-Nowak and colleagues /77-80/ investigated the effects of ganglioside treatment on the sprouting response which results from partial denervation of the cholinergic input to the hippocampus (HPC). Following damage to the septum, there is an initial decrease in the enzymes acetylcholinesterase (AChE) and choline acetyltransferase (ChAT) in the HPC which is then followed by a progressive recovery of enzymatic activity over the next several months $/ 75,79 /$. The recovery of neurochemical activity correlates with the appearance of newly formed synaptic contacts in the HPC and is considered to be an accurate marker of sprouting of surviving hippocampal afferents. Following electrocoagulation lesions, a mixture of gangliosides accelerated the recovery of $\mathrm{AChE}$ and ChAT activity in the HPC $/ 77,79,80$ /. While the initial decline in enzymatic activity was equivalent regardless of whether the animals received gangliosides or not, gangliosides produced a significant increase in AChE and ChAT activity compared to controls at both 18 and 50 days post-surgery. These same investigators reported that ganglioside GM1 promoted sprouting following ablations of the entorhinal cortex /78/. At 3 weeks following surgery, GM1 enhanced the recovery of AChE and ChAT activity in the HPC indicating an enhancement of the sprouting response of the septohippocampal pathway. 
Given that gangliosides appeared to enhance the plasticity of the septohippocampal cholinergic pathway, investigators examined the behavioral consequences of this accelerated response. Karpiak /57/ examined the performance of rats on a spatial alternation task following unilateral lesions of the entorhinal cortex. Animals receiving daily injections of GM1 made significantly fewer errors on the first postoperative day compared to lesioned animals not receiving ganglioside treatment. Because this reduction in the lesion-induced behavioral deficits preceded the period of time considered necessary for reinnervation to begin, these results were interpreted as indicating that GM1 exerted a protective rather than regenerative effect. To evaluate this possibility Fass and Ramirez /36/ bilaterally lesioned the entorhinal cortex producing increases in open-field activity which typically recover over a two week period. Animals treated with GM1 were less active than lesioned animals receiving saline treatment as early as two days post-surgery suggesting that the behavioral protection was independent of alterations in the sprouting response. Furthermore, a reduction in the density of $\mathrm{AChE}$ staining was observed in the dentate gyrus of animals treated with gangliosides indicating that GM1 might have actually suppressed the sprouting response. The interpretation of these results was further complicated by a comparison between the behavioral and histological analysis which revealed that there was no obvious relationship between the recovery of the behavioral impairments and the alterations in AChE staining. Poplawsky and Isaacson /84/ further demonstrated that ganglioside treatment decreased the hyper-emotionality following septal lesions. Again, these changes were observed within two days following surgery, making it unlikely that structural changes, such as sprouting, accounted for the observed behavioral effects.

More recently, Emerich and Walsh /34/ examined the effects of ganglioside AGF2 (the internal ester of GM1) on the behavioral and neurochemical consequences of bilateral injections of ethylcholine mustard aziridinium ion $(\mathrm{AF} 64 \mathrm{~A})$ into the lateral ventricles of rats.
AF64A produced an impairment on both a standard radial arm maze (RAM) task and when a 1 hour delay was imposed between the fourth and fifth arm choices. Although the initial impairment was equivalent regardless of whether the AF64A-treated animals received AGF2 or saline, the AGF2-treated rats recovered on the standard RAM task within 4 weeks but were permanently impaired on the delay version of the task. Neurochemical analysis revealed that AGF2 enhanced ChAT activity in the hippocampus at 20, but not 2 or 11 weeks following surgery. Cell counts of cholinergic neurons in the medial septum revealed that AGF2 did not reduce the extent of neuronal loss. As in the study by Fass and Ramirez /36/, these data indicated that AGF2 might have enhanced the sprouting of cholinergic terminals following the initial insult, but that the behavioral recovery exhibited by these animals was incomplete and unrelated to that sprouting.

It appears, then, that there is no clear evidence which directly links ganglioside-induced sprouting to behavioral recovery following damage to central cholinergic systems. Gangliosides have been shown to influence behavioral recovery at times too early to be accounted for by structural changes or at times removed from the occurrence of such changes 134,36,57,84/. The interpretation of the relationship of sprouting to behavioral recovery is also complicated by the methods used to assess sprouting. Changes in enzyme levels do not necessarily reflect an effect of ganglioside on sprouting. Rather gangliosides could be modulating a lesion-induced up-regulation of transmitter biosynthesis and release. Gangliosides could also directly stimulate the activity of the enzymes involved in the synthesis of acetylcholine (ACh). Cuello and colleagues /20/ found that GM1 significantly increased ChAT activity in the nucleus basalis in sham-operated rats. In addition, Hefti et al. /49/ reported that a ganglioside mixture directly increased ChAT activity in cultures of dissociated fetal septal neurons without altering fiber outgrowth of those cholinergic neurons. Accordingly, gangliosides might enhance ChAT activity following septal lesions by increasing the activity of this 
enzyme in surviving neurons. However, enhanced sprouting and direct stimulation of ChAT activity need not be mutually exclusive events and might act in a coordinated manner to create a more conducive neural environment for the initiation of structural repair processes which promote functional recovery.

\section{Nigrostriatal dopamine system}

The nigrostriatal dopamine system also lends itself to an analysis of the correlation between behavioral recovery and regeneration/ reinnervation processes. Transections of the nigrostriatal tract result in a marked reduction in tyrosine hydroxylase (TH) and homovanillic acid (HVA) content in the denervated caudate. Behaviorally, rats with unilateral lesions exhibit a stereotyped rotational behavior when challenged with dopaminergic agonists such as apomorphine or amphetamine. Toffano and colleagues /113115/ reported that gangliosides reduced the number of apomorphine-induced rotations at 14 and 30 , but not 8 days, following a unilateral hemitransection of the nigrostriatal pathway. It was also reported that $\mathrm{TH}$ levels in salinetreated controls were $50 \%$ of normal while animals receiving gangliosides exhibited only a $20 \%$ decrease in TH. Increased levels of HVA and $\mathrm{TH}$-immunofluorescence substantiated the ganglioside related increase in dopaminergic activity at the later, but not earlier, time points. Since this time course coincided with that expected for terminal reinnervation of the striatum, it was concluded that gangliosides enhanced behavioral recovery through increased sprouting of dopaminergic fibers. However, the interpretation of these studies are also subject to the possibility that gangliosides simply increased HVA and TH activity through a compensatory increase in neurotransmitter synthesis and release. Following damage, surviving dopaminergic neurons increase their rate of synthesis and metabolic activity. Ganglioside treatments might act to accelerate this process, thereby affording the animal some degree of behavioral recovery.

To address this issue more carefully, Sabel $e t$ al. /92,94/ injected HRP into the striatum following transection of the nigrostriatal pathway. It was assumed that if GM1 ganglioside was promoting sprouting then an increased number of HRP-positive cells should be visualized within the substantia nigra. At postoperative day 3 there were no differences in the number of labeled cells between the saline and GM1-treated animals. However, at day 15 there were significantly more labeled neurons in those animals treated with GM1. While these results strongly suggested that GM1 stimulated reorganizational processes, these same processes do not necessarily underlie behavioral recovery. In fact, a clear dissociation of behavioral and morphological recovery was observed in these studies. While ganglioside-treated animals exhibited decreases in rotational behavior as early as two days following surgery, there were no apparent differences in HRP-labeled cells in the substantia nigra. Although these two indices may correlate at later time points, the proposed sprouting of dopaminergic fibers cannot account for this early behavioral recovery.

Other studies have failed to find a clear correlation between anatomical/neurochemical and behavioral recovery following ganglioside treatment. Sabel et al. /93/ reported that gangliosides ameliorated the deficits in spatial alternation behavior following bilateral electrolytic lesions of the caudate nucleus. Upon histological evaluation, it was revealed that there were no differences in the number of neurons or glia adjacent to the lesion site or in the substantia nigra between those lesioned animals receiving gangliosides and those receiving vehicle control injections. While a protective effect of gangliosides was not likely in these studies, the role of sprouting remains a possible contributor to the observed functional recovery. Dunbar et al. $130 /$ examined the effects of gangliosides on rotational behavior, aphagia and adipsia following complete transections of the nigrostriatal pathway. Following total lesions, gangliosides were ineffective in reducing amphetamine-induced rotational behavior $130 \%$ However, these same ganglioside-treated animals demonstrated a significant attenuation of the initial decrease in body weight. Together with previous neurochemical studies, these data 
suggested that there may be a dissociation between functional and neurobiological recovery in ganglioside-treated animals.

\section{Other systems}

The ability of gangliosides to promote sprouting has been evaluated in a variety of other neural regions. Kojima et al. /62/ infused 6hydroxydopamine (6-OHDA) into the cerebral cortex via an osmotic minipump. Fluorescent histochemistry and neurochemical analysis revealed a significant loss of fluorescent nerve terminals and norepinephrine (NE) levels in the cortex within 3-7 days. Within 5 weeks there was a reappearance of nerve terminals within the damaged region. Treatment with ganglioside GM1 significantly elevated NE levels at 7 and 14 days following 6-OHDA with no effect on the initial loss of NE terminals.

Jonsson et al. $155 /$ reported that GM1 restored serotonin (5-HT) levels in the cortex following systemic injections of the serotonergic neurotoxin 5,7-DHT. Again, GM1 had no effect on the initial loss of 5-HT terminals, rather the effects were observed to occur following the initial result.

Fujito et al. /41,42/ conducted a series of experiments which suggested that gangliosides promoted sprouting in the red nucleus of kittens. Following neocortical damage, the probability of producing excitatory postsynaptic potentials (EPSPs) in the red nucleus decreased to approximately $20 \%$. Gradually, EPSPs reappeared, indicating a sprouting response of the previously degenerating cortical afferents. Placement of a sponge containing a crude ganglioside extract into the wound cavity resulted in an increased probability of inducing EPSPs in the red nucleus at 3 weeks post-lesion. These data indicated that gangliosides promoted a sprouting response and that this response had a functional consequence (i.e., production of EPSPs).

Other investigators have suggested that gangliosides promote sprouting in the spinal cord following transections $/ 10,19 /$ and in the hamster visual system following lesions of the superior colliculus /98/.

\section{GANGLIOSIDE-INDUCED PREVENTION OF NEURONAL DEGENERATION}

The foregoing discussion strongly suggests that ganglioside-induced enhancement of sprouting does not necessarily account for the promotion of functional recovery. Given that behavioral recovery processes have been frequently reported to occur relatively soon following injury (i.e., at times prior to the initiation of sprouting), a more parsimonious explanation for these effects might be that they limit the extent of neuronal damage produced immediately following surgery. The following section reviews the evidence for this possibility and discusses possible biological mechanisms underlying this prophylactic effect.

\section{Nucleus basalis-cortical cholinergic system}

Following lesions of the magnocellular nuclei, high affinity choline uptake (HAChU) and ChAT activity is decreased by approximately $50 \%$ in the frontal cortex. Treatment with GM1 prevented the decreases in HAChU in the frontal and parietal cortex as early as 4 days following surgery $/ 82 /$. Because of this early time course of recovery, the sparing of HAChU cannot be accounted for by collateral sprouting. Following unilateral cortical lesions, GM1 also prevented the retrograde cell atrophy in the nucleus basalis /20/. Accompanying this attenuation was a significant protection against the loss of ChAT activity in this same region. Unfortunately, a time course analysis was not performed to determine whether GM1 actually prevented or reversed the cell shrinkage.

Casamenti and colleagues /17/ confirmed that ganglioside treatment not only prevents the loss of cortical cholinergic parameters following damage but also improves the rate of acquisition of an active avoidance task. These behavioral effects were observed during the initial stages of behavioral testing (4-7 days post-surgery) and ruled out the possibility that collateral sprouting underlay the observed alterations in cholinergic function. Rather, these results may be interpreted as indicating that GM1 either 
prevented terminal degeneration or produced compensatory increases in cholinergic enzymatic activity at time points shortly following injury. The contention that exogenous ganglioside administration attenuates the initial consequences of damage to the magnocellular nuclei is supported by a recent study by Cuello and colleagues $/ 20 /$. These investigators reported that GM1 prevented the retrograde atrophy and loss of cholinergic neurons in the nucleus basalis following cortical damage. Importantly, this effect was observed both following systemic administration of GM1 and following the placement of microencapsulated GM1 onto the damaged cortical surface /71/. Elliott and colleagues $/ 31$ / examined the effects of GM1 on the neurochemical and behavioral changes produced by unilateral devascularizing lesions of the neocortex. Following surgery, animals exhibited a series of behavioral alterations, including hyperactivity, motor uncoordination, impaired passive avoidance retention and reacquisition, and decreased retention of a Morris water maze task. Infusion of GM1 directly into the lateral ventricles via minipumps prevented the retrograde degeneration of cholinergic nuclei in the nucleus basalis and enhanced the reacquisition of both the passive avoidance and water maze task but had no effect on the hyperactivity or motor coordination tasks.

\section{Septohippocampal cholinergic system}

Ganglioside-induced prevention of cholinergic cell loss has also been reported following damage to the septohippocampal cholinergic system. DiParte et al. /27/ reported that the intraventricular injection of vincristine decreased ChAT and HAChU in the HPC and that these decreases were prevented by prior treatment with ganglioside GM1. Sofroniew et al. /104/ further demonstrated that gangliosides prevented the retrograde cell loss in the medial septum and vertical limb of the diagonal band following hippocampal ablation.

To evaluate the ability of gangliosides to prevent damage to the septohippocampal cholinergic system and the associated behavioral consequences, a series of studies using the neurotoxin colchicine were conducted /33,35/. Intraventricular administration of colchicine produced marked decreases in hippocampal ChAT activity and HAChU levels without damage to hippocampal granule cells which are susceptible to direct administration of colchicine. Behaviorally, colchicine-treated animals exhibited a pronounced hyperactivity and marked cognitive deficits which were prevented by AGF2 administration. While previous studies had indicated that gangliosides produced a task dependent behavioral recovery $/ 17,34 /$ the recovery in these studies was complete. Lesioned animals receiving AGF2 were able to perform a radial arm maze task as well as controls, even when a delay as long as four hours was imposed between the fourth and fifth arm choices. Neurochemical and anatomical analyses indicated that AGF2 prevented the decreases in hippocampal ChAT and HAChU as well as the loss of cholinergic neurons in the medial septum. These data clearly indicated that gangliosides are capable of preventing the biochemical, anatomical and behavioral consequences of neural damage.

Interestingly, ganglioside treatment appeared to exert a different profile of effects following intradentate injections of colchicine. Following intrahippocampal administration, colchicine produced extensive decreases in the thickness of both the superior and inferior blades of the dentate gyrus and an associated retrograde degeneration of cholinergic neurons in the medial septum /32,33/. GM1 administration facilitated the recovery of normal locomotor activity, attenuated the impaired retention of a passive avoidance task and reduced the llterations in sensitivity to the motor stimulating effects of apomorphine and the analgesic effects of morphine /118/. Furthermore, both GM1 and AGF2 facilitated recovery of working memory in a multiple component T-maze task /32/. However, quantitative analysis revealed that despite the facilitative effects of ganglioside treatment on behavior, there was no obvious reduction in the extent of colchicine-induced granule cells destruction or the retrograde degeneration of cholinergic neurons in the medial septum. 
In contrast to the failure to find any anatomical correlate to the ganglioside-induced behavioral recovery following intrahippocampal colchicine, biochemical evidence suggesting a possible protective effect of GM1 has been obtained. Following intrahippocampal injections of colchicine, Walsh et al. /119/ examined the effects of GM1 on the expression of ornithine decarboxylase (ODC) activity in the HPC. Ornithine decarboxylase is the rate-limiting enzyme in the synthesis of the polyamines putrescine, spermine, and spermidine and has been suggested to provide a reflection of the extent of neural damage present. Following unilateral injections of colchicine into the dentate gyrus, ODC activity increased 8-fold in the HPC. Prior treatment with GM1 ganglioside significantly reduced this response on the ipsilateral side but enhanced the ODC response on the contralateral side. These gangliosideinduced changes were independent of any protective action of GM1 on hippocampal morphology. Since changes in ODC activity are correlated with the magnitude of neural damage, it appeared that GM1 may have altered some of the secondary consequences of hippocampal damage.

The mechanism by which gangliosides exert their protective effects on cholinergic systems is unclear but may relate to the interaction of gangliosides with endogenous neurotrophic factors at or near the site of injury. Several lines of evidence indicate that gangliosides augment endogenous biological responses that are initiated by injury and subserve neuroplasticity. It is well established that levels of endogenous trophic factors increase following neural damage $174,75 /$. Furthermore, the early administration of trophic agents, including nerve growth factor (NGF) and gangliosides, are effective in reducing both cell death and the behavioral deficits associated with neural injury $/ 21,22$, $27,31,35,50,63,107,122 /$. The typical increases in injury mediated trophic factors may not be sufficient to prevent the lesion-induced cell loss which occurs immediately following injury, or these increases may occur at a time subsequent to the majority of cell loss. The administration of compounds capable of interacting with endogenous trophic factors or altering the response of neurons to the levels of endogenous trophic factors may represent one method for minimizing injury related cell loss. Gangliosides have been suggested to exert their trophic effects by interacting with endogenous NGF. This suggestion is supported by several convergent lines of evidence: (1) gangliosides and NGF promote cell survival and increase ChAT activity in the nucleus basalis in a synergistic manner following cortical damage $/ 20 /$; (2) GM1 potentiates the ability of NGF to prevent the decreases in norepinephrine levels in the heart, spleen and kidneys following systemic administration of vincristine /117/; (3) GM1 initiates neurite outgrowth in fetal chick dorsal root ganglionic cells and PC12 cells in a NGFdependent manner $/ 28,103 /$, and (4) the ability of GM1 to prevent the loss of cholinergic neurons in the nucleus basalis diminishes as the age of the animal increases and the normal and lesioninduced levels of trophic factors decrease /107/.

Although the exact mechanism by which gangliosides potentiate the actions of NGF remains unknown, it may relate to a modification of membrane surface properties subsequent to the incorporation of gangliosides into the membrane. Unfortunately Ferrari /39/ failed to find increased binding of NGF to PC12 cells following ganglioside treatment. However, gangliosides could still conceivably modulate a variety of neuronal processes including surface transduction or specific NGF related posttranslational events (see $/ 22 /$ and $/ 101 /$ for reviews).

Gangliosides may also alter axonal transport and in turn increase the availability of NGF or other trophic factors to deprived neurons. Gangliosides promote the formation of microfilament networks in cultured neuroblastoma cells /106/ as well as stimulating tubulin gene expression following transections of the nigrostriatal pathway $/ 126 /$. By accelerating or promoting the organization of cytoskeletal elements, gangliosides may enhance the transport and subsequent availability of trophic factors such as NGF under normal conditions and following injury. The ability of gangliosides to modulate the regeneration of damaged nerves 
by altering the axoplasmic transport of macromolecules has been investigated following nerve crush of the optic nerve in goldfish. Following nerve crush, the optic nerve regenerates over a 2-4 week period in parallel with increased visual acuity $123,24 /$. SbaschnigAgler et al. /100/ reported an 8-fold increase in the axonal transport of gangliosides following crush of the optic nerve. This increase was evident within 8 days following surgery and persisted for up to 25 days. In addition, intraocular injections of antibodies to gangliosides inhibited the regeneration of the optic nerve following nerve crush /105/. Daily injections of antiserum beginning 5 days prior to surgery resulted in a $40 \%$ decrease in the distance of axonal outgrowth measured 10 days after the crush. These data suggested that gangliosides may play a role in neural outgrowth and regeneration by modulating the transport of various macromolecules such as NGF.

\section{Nigrostriatal dopamine system}

As already mentioned, the evidence supporting a role for gangliosides in mediating behavioral recovery via sprouting of surviving dopaminergic afferents is questionable. Several lines of evidence indicate that behavioral recovery occurs at time points too early to be accounted for by structural changes. On the other hand, there is evidence to suggest that gangliosides may act to reduce the initial consequences of damage to this system.

Within 2 weeks following a partial hemitransection of the nigrostriatal pathway, animals treated with gangliosides exhibit an attenuated decrease in TH activity. Toffano et al. /116/ reported that this amelioration was associated with a ganglioside-induced reduction of the loss of dopamine neurons. Both the TH and immunocytochemical indices necessarily use dopamine to evaluate cell number and these results could also be interpreted as indicating that gangliosides are simply increasing transmitter synthesis.

In an attempt to evaluate more carefully the possible protective effects of gangliosides, Sabel et al. /97/ used the Fink-Heimer technique to quantify the extent of anterograde degeneration in the substantia nigra following hemitransections of the nigrostriatal pathway in the left hemisphere and an electrolytic caudate lesion in the right hemisphere. Seven days following the lesion, the animals treated with GM1 had significantly smaller areas of neuronal degeneration on the side with the caudate lesion than those animals treated with saline. In contrast, there was no effect of ganglioside treatment on the side with the hemitransection. While GM1 had no effect following the hemitransection in these studies, Raiteri and colleagues /88/ reported that AGF2 decreased the reduction of $\left[{ }^{3} \mathrm{H}\right]$ dopamine uptake into striatal synaptosomes five days following surgery. Although not conclusive, the combined anatomical and neurochemical data suggest that gangliosides exert some protective effect following damage to the nigrostriatal system.

The contention that gangliosides produce behavioral recovery by minimizing cell damage is supported by a study by Li et al. /67/. Two days following unilateral nigrostriatal transections, amphetamine-induced rotational behavior was reduced by ganglioside treatment. The ganglioside treatment also prevented the loss of striatal $\mathrm{Na}^{+}, \mathrm{K}^{+}$-ATPase activity typically observed following damage. Two days following transection, the level of $\mathrm{Na}^{+}, \mathrm{K}^{+}$-ATPase was decreased $36 \%$ in lesioned animals but only $7 \%$ in lesioned animals receiving gangliosides. Because increased $\mathrm{Na}^{+}, \mathrm{K}^{+}$-ATPase activity had been previously shown to correlate with the extent of edema, it was concluded that the gangliosides had minimized the extent of edema and in turn promoted functional recovery.

\section{Ischemia}

Karpiak and colleagues have used a model of transient cerebral ischemia to investigate the effects of gangliosides on behavioral recovery 158/. In particular, this model has been employed to evaluate the suggestion that gangliosides produce their effects through the induction of discrete metabolic events immediately after damage. The most studied metabolic alterations 
concern the ability of gangliosides to reduce the decrease in membrane $\mathrm{Na}^{+}, \mathrm{K}^{+}$-ATPase which occurs following cell damage. Gangliosides produced a $33 \%$ reduction in edema 48 hours following cortical damage in rats $/ 58 /$. This reduction was accompanied by a significant attenuation of lesion-induced reduction in plasma $\mathrm{Na}^{+}, \mathrm{K}^{+}$-ATPase levels and paralleled enhanced cerebral blood flow, reduced cell damage, electrocorticographic alterations and neurological deficits $/ 14 /$.

There have been a limited number of clinical studies examining the effects of gangliosides in human stroke patients. Bassi /7/ reported that patients receiving gangliosides had a higher level of neurological functioning than a similar group of individuals treated with placebo. Likewise, Battistin /8/ demonstrated that ganglioside treatment resulted in improved neurophysiological ratings in patients with cerebrovascular disease. Importantly, the ganglioside treatment in both these studies was effective even though it began at least 10 days following the initial lesion. Therefore, it may not be absolutely necessary to administer gangliosides during the acute phase of such an injury. Such a treatment may still be effective during the subacute phase and might actually exert a more powerful effect if given earlier.

\section{CONCLUSIONS}

Gangliosides appear to be capable of producing potent behavioral recovery following a variety of CNS perturbations $/ 16,17,20,30,32,34$, $35,82,89,92-97,113,115,120 /$. Gangliosides have been shown to reduce motor and cognitive deficits in laboratory animals as well as the clinical signs of neurological functioning in humans. In contrast, only a small number of studies has failed to demonstrate a beneficial effect of ganglioside treatment $/ 11,17,30,34,84 /$. Importantly, in those studies failing to show any significant improvement following ganglioside treatment in humans, there have not been any demonstrated deleterious effects. For instance, chronic administration (up to 12 months) of GM1 ganglioside to Alzheimer's patients did not result in any neurological improvement but had no toxic side effects either, demonstrating the long-term safety of chronic ganglioside treatment 13/. Unfortunately, these investigators were not able to determine if the GM1 treatment significantly slowed the progression of the disease. Recent studies have suggested that antibodies to GM1 are present in high levels in individuals afflicted with Guillain Barre syndrome, suggesting that chronic administration of gangliosides could contribute to the development of this disease $/ 87,127 /$. However, a recent study failed to reveal antibody formation following parenteral injection of gangliosides in Alzheimer patients /110/. Nevertheless, the possibility of untoward side effects from ganglioside treatment deserves serious attention prior to large scale clinical trials. The possibility of side effects further underscores the need to determine the mechanism underlying gangliosideinduced recovery.

Several lines of evidence suggest that gangliosides promote sprouting of CNS neurons and that this sprouting response mediates behavioral recovery $192,93,113-115 /$. However, there are also numerous studies which seriously question this conclusion $134,36,57,84 /$. Most of the evidence of ganglioside-induced sprouting is based on observations of increased transmitter levels or their metabolites. Additionally, increased retrograde cell labeling has been provided as evidence of enhanced sprouting. These indices do not, however, provide direct evidence of enhanced sprouting and could simply reflect increased transmitter levels, enzyme activity, axonal transport processes or a unique combination of these events. Future studies using electron microscopy, tract tracing techniques, autoradiography, electrophysiology and in vitro techniques are needed to substantiate ganglioside-induced sprouting.

Regardless of whether gangliosides do actually promote sprouting, it appears that this is not always the basis of behavioral recovery. Functional recovery has been frequently reported prior to, or independent of, measures indicative of sprouting $134,36,84 /$. Such a dissociation suggests that events which precede sprouting may be the basis for some observed 
recovery. Although few studies have actually demonstrated neuronal sparing following ganglioside treatment, some have provided direct evidence of a protective effect $/ 20,35 /$. While either an enhancement of sprouting or a prophylactic effect of gangliosides is appealing, neither can account for all observed behavioral recovery. It appears then that a variety of factors, including the type, location, and extent of the lesion, may affect the ability of gangliosides to modulate behavioral recovery. Further complicating our understanding of recovery are questions concerning the effective species of gangliosides for eliciting recovery from various lesion types, as well as practical considerations, including the doses, timing and route of administration and which portion of ganglioside molecule is responsible for an observed effect. These considerations withholding, gangliosides appear to be useful for treating a variety of CNS injuries. Although not a panacea, answers to the above questions may accelerate our development of an efficacious and rational approach for using gangliosides or other pharmacological treatments as primary or adjunct therapies in disorders of the CNS.

\section{REFERENCES}

1. Agnati LF, Fuxe $\mathrm{K}$, Calza L, Benfanati $\mathrm{F}$, Cavicchioli L, Toffano G, Goldstein M. Gangliosides increase the survival of lesioned nigral dopamine neurons and favour the recovery of dopaminergic synaptic function in striatum of rats by collateral sprouting. Acta Physiol Scand 1983; 119: 347-363.

2. Agnati LF, Fuxe K, Calza L, Goldstein M, Toffano G, Giardino L, Zoli M. Further studies on the effects of the GM1 ganglioside on the degenerative and regenerative features of mesostriatal dopamine neurons. Acta Physiol Scand 1984; 532: 37-44.

3. Ala T, Romero S, Knoght F, Feldt K, Frey WH. GM-1 treatment of Alzheimer's disease. Arch Neurol 1991; 47: 1126-1130.

4. Aldinio C, Valenti G, Savoini G, Kirkschner G, Agnati LF, Toffano G. Monosialoganglioside internal ester stimulates the dopaminergic reinnervation of the striatum after unilateral hemitransection in rat. Int J Dev Neurosci 1984; 2: 267-275.

5. Ando S. Gangliosides in the nervous system.
Neurochem Int 1983; 5: 507-537.

6. Baker RE, Van der Togt C. Gangliosides restore the specificity of afferent projection patterns in spinal cord explants chronically exposed to tetrodotoxin. Neurosci Lett 1986; 67: 285-288.

7. Bassi S, Albizzati MG, Sbacchi M, Frattola L, Massarotti M. Double blind evaluation of monosialoganglioside (GM1) therapy in stroke. J Neurosci Res 1984; 12: 493-498.

8. Battistin L, Cesari A, Galligioni F, Marin G, Massarott M, Paccagnella D, Pellegrini A, Testa G, Tonin P. Effects of GM1 ganglioside in cerebrovascular diseases: a double-blind trial in 40 cases. Eur Neurol 1984; 24: 343-351.

9. Bianchi R, Marini P, Merlini S, Fabris M, Triban C, Mussini E, Fiori MG. ATPase activity defects in alloxan-induced diabetic sciatic nerve recovered by ganglioside treatment. Diabetes 1988; 37: 13401345.

10. Bose B, Osterholm JL, Kalia M. Gangliosideinduced regeneration and reestablishment of axonal continuity in spinal cord-transected rats. Neurosci Lett 1986; 63: 165-169.

11. Butler WM, Griesbach E, Labbe R, Stein DG. Gangliosides fail to enhance behavioral recovery after bilateral ablation of the visual cortex. J Neurosci Res 1987; 17: 404-409.

12. Byrne MC, Leeden RW, Roisen FJ, Yorke G, Sclafani JR. Ganglioside-induced neuritogenesis: Verification that gangliosides are the active agents, and comparison of molecular species. J Neurochem 1983; 41: 1214-1222.

13. Caccia MR, Meola G, Cerri C, Frattola L, Scarlato G, Aporti F. Treatment of denervated muscle by gangliosides. Muscle Nerve 1979; 2: 382-389.

14. Cahn J, Borzeix M-G, Toffano G. Effect of GM1 ganglioside and of its inner ester derivative in a model of transient ischemia in the rat. In: Tettamanti G, Leeden RW, Sandhoff K, Nagai Y, Toffano G, eds., Gangliosides and Neuronal Plasticity. Berlin: Springer-Verlag, 1987; 435-443.

15. Carine K, Schengrund C-L. Effects of exogenous GM1 and GD1a on S20Y neuroblastoma cells. J Neurosci Res 1984; 12: 59-69.

16. Carmignoto $G$, Canella $R$, Bisti S. Can functional reorganization of area 17 following monocular deprivation be modified by GM1 internal ester treatment? J Neurosci Res $1984 ; 12:$ 477-483.

17. Casamenti F, Bracco L, Bartolini L, Pepeu G. Effects of ganglioside treatment in rats with a lesion of the cholinergic forebrain nuclei. Brain Res 1985; 338: 45-52.

18. Ceccarelli B, Aporti F, Finesso M. Effects of brain gangliosides on functional recovery in experimental regeneration and reinnervation. Adv Exp Med Biol 
1976; 71: 275-293.

19. Commissiong JW, Toffano G. The effect of GM1 ganglioside on coerulospinal noradrenergic, adult neurons and on fetal monoaminergic neurons transplanted into the transected spinal cord of the adult rat. Brain Res 1986; 380: 205-215.

20. Cuello AC, Stephens PH, Tagari PC, Sofroniew MV, Pearson RCA. Retrograde changes in the nucleus basalis of the rat, caused by cortical damage, are prevented by exogenous ganglioside GM1. Brain Res 1986; 376: 373-377.

21. Cuello AC, Garofalo L, Kenigsberg RL, Maysinger D. Gangliosides potentiate in vivo and in vitro effects of nerve growth factor on central cholinergic neurons. Proc Natl Acad Sci USA 1989; 86: 20562060.

22. Dal Toso R, Skaper SD, Ferrari G, Vantini G, Toffano G, Leon A. Ganglioside involvement in membrane mediated transfer of trophic information. In: Stein DG, Sabel BA, eds, Pharmacological Approaches to the Treatment of Brain and Spinal Cord Injury. New York: Plenum Press, 1989; 143-165.

23. Davis RE, Schlumpf BE, Klinger PD. Systemic colchicine inhibits goldfish optic nerve regeneration. Toxicol Appl Pharmacol 1984; 73: 268-274.

24. Davis RE, Schlumpf BE, Klinger PD. Comparative neurotoxicity of tubulin-binding drugs: inhibition of goldfish optic nerve regeneration. Toxicol Appl Pharmacol 1985; 80: 308-315.

25. Dienel GA, Cruz NF. Induction of ornithine decarboxylase during brain recovery from metabolic, mechanical, thermal or chemical injury. J Neurochem 1984; 42: 1053-1061.

26. Dimpfel W, Moller W, Mengs U. Gangliosideinduced neurite formation in cultured neuroblastoma cells. In: Rapport MM, Gorio A, eds, Gangliosides in Neurological and Neuromuscular Function, Development and Repair. New York: Raven Press, 1985; 119-134.

27. DiParte PI, Abbamondi A, Bartolini A, Pepeu G. GM1 ganglioside counteracts cholinergic and behavioral deficits in the rat induced by intracerebral injection of vincristine. Eur J Pharmacol 1989; 162: 43-50.

28. Doherty P, Dickson JG, Flanigan TP, Walsh FS. Ganglioside GM1 does not initiate, but enhances neurite regeneration of nerve growth factordependent sensory neurons. J Neurochem 1985; 44: 1259-1265.

29. Dreyfus H, Ferret B, Harth S, Gorio A, Freysz L, Massarelli R. Metabolism and function of gangliosides in developing neurons. J Neurosci Meth 1984; 12: 311-322.

30. Dunbar GL, Butler WM, Fass B, Stein DG.
Behavioral and neurochemical alterations induced by exogenous ganglioside in brain damaged animals. In: Tettamanti G, Leeden RW, Sandhoff K, Nagai Y, Toffano G, eds., Problems and Perspectives. Gangliosides and Neuronal Plasticity. Berlin: Springer Verlag, 1987; 365-380.

31. Elliott PJ, Garofalo L, Cuello AC. Limited neocortical devascularizing lesions causing deficits in memory retention and choline acetyltransferase activity: effects of the monosialoganglioside GM1. Neuroscience 1989; 31: 63-76.

32. Emerich DF, Walsh TJ. Selective working memory impairments following intradentate injection of colchicine: attenuation of the behavioral but not the pathological effects by gangliosides GM1 and AGF2. Physiol Behav 1989; 45: 93-101.

33. Emerich DF, Walsh TJ. Cholinergic cell loss and cognitive impairments following intraventricular or intradentate injection of colchicine. Brain Res 1990; 517: 157-167.

34. Emerich DF, Walsh TJ. Ganglioside AGF2 promotes task-specific recovery and attenuates the cholinergic hypofunction induced by AF64A. Brain Res 1990; 527: 299-307.

35. Emerich DF, Walsh TJ. Ganglioside AGF2 prevents the cognitive impairments and cholinergic cell loss following intraventricular colchicine. Exp Neurol 1991; 112: 328-337.

36. Fass B, Ramirez JJ. Effects of ganglioside treatments on lesion-induced behavioral impairments and sprouting in the CNS. J Neurosci Res 1984; 12: 445-458.

37. Favaro G, Di Gregorio F, Panozzo C, Fiori MG. Ganglioside treatment of vincristine-induced neuropathy. An electrophysiologic study. Toxicology 1988; 49: 325-329.

38. Favaron M, Manev $\mathrm{H}$, Alho H, Bertolino M, Ferret B, Guidotti A, Costa E. Gangliosides prevent glutamate and kainate neurotoxicity in primary neuronal cultures of neonatal rat cerebellum and cortex. Proc Natl Acad Sci USA 1988; 85: 73517355.

39. Ferrari G, Fabris M, Gorio A. Gangliosides enhance neurite outgrowth in PC12 cells. Dev Brain Res 1983; 8: 215-219.

40. Fishman PH, Brady RO. Biosynthesis and function of gangliosides. Science 1976; 194: 906-915.

41. Fujito Y, Watanabe S, Kobayashi H, Tsukahara N. Lesion-induced sprouting in the red nucleus at the early development stage. In: Finger S, Almli CR, eds, Early Brain Damage, Volume 2. New York: Academic Press, 1984; 35-47.

42. Fujito Y, Watanabe S, Kobayashi H, Tsukahara N. Promotion of sprouting and synaptogenesis of cerebrofugal fibers by ganglioside application in the 
red nucleus. Neurosci Res 1985; 2: 407-411.

43. Fusco M, Dona M, Tessari F, Hallman H, Jonsson G, Gorio A. GM1 ganglioside counteracts selective neurotoxin-induced lesion of developing serotonin neurons in rat spinal cord. J Neurosci Res 1986; 15: 467-479.

44. Gorio AP, Marini P, Zononi R. Muscle reinnervation III. Motorneuron sprouting capacity, enhancement by exogenous gangliosides. Neuroscience 1983; 8: 417-429.

45. Gorio AP, Carmignoto G, Finesso M, Leon A, Marini P, Tredese L, Zaroni R. Electrophysiological and morphological correlates of the reinnervation of the rat neuromuscular junction: Implications on the role of membrane components such as gangliosides in the motor nerve sprouting. Adv Behav Biol 1981; 25: 221-233.

46. Gradkowska M, Skup M, Kiedrowski L, Calzolari S, Oderfeld-Nowak B. The effect of GM1 ganglioside on cholinergic and serotonergic systems in rat hippocampus following partial denervation is dependent on the degree of fiber degeneration. Brain Res 1986; 375: 417-422.

47. Hadjiconstantinou M, Neff NH. Treatment with GM1 ganglioside restores striatal dopamine in the 1-methyl-4-phenyl-1,2,3,6-tetrahydropyridinetreated mouse. J Neurochem 1988; 51: 1190-1196.

48. Hadjiconstantinou M, Neff NH. Treatment with GM1 ganglioside increases rat spinal cord indole content. Brain Res 1986; 366: 343-345.

49. Hefti F, Hartikka J, Frick W. Gangliosides alter morphology and growth of astrocytes and increase the activity of choline acetyltransferase in cultures of dissociated septal cells. J Neurosci 1985; 5: 20862094.

50. Hefti FJ. Nerve growth factor (NGF) promotes survival of septal cholinergic neurons after fimbrial transections. J Neurosci 1986; 6: 2155-2162.

51. Heiskanan O, Melamad A. Prognosis of severe brain injury. Acta Neurol Scand 1970; 46: 343.

52. Heywood R, Chesterman H, Hunter B, Palmer AK, Majeed SK, Pretice DE. The toxicology of a ganglioside extract (cronassial). Toxicol Lett 1983; 15: 275-282.

53. Horowitz SH. Ganglioside therapy in diabetic neuropathy. Muscle Nerve 1986; 9: 531-536.

54. Huamin RY, Lago A, Moral A, Sevilla MT, Piqueras A. Gangliosides in the treatment of idiopathic facial paralysis (Bell's palsey). Curr Ther Res 1986; 40: 29-34.

55. Jonsson $G$, Gorio A, Hallman $H$, Janigro $D$, Kojima H, Luthman J, Zanoni R. Effects of GM1 ganglioside on developing and mature serotonin and noradrenaline neurons lesioned by selective neurotoxins. J Neurosci Res 1984; 12: 459-476.
56. Kalia M, DiPalma JR. Ganglioside-induced acceleration of axonal transport following nerve crush injury in the rat. Neurosci Lett 1982; 34: 1-5.

57. Karpiak SE. Ganglioside treatment improves recovery of alternation behavior after unilateral entorhinal cortex lesion. Exp Neurol 1983; 81: 330339.

58. Karpiak SE, Mahadik SP. Reduction of cerebral edema with GM1 ganglioside. J Neurosci Res 1984; 12: 485-492.

59. Kasarskis E, Karpiak SE, Rapport MM, Yu R, Bass $\mathrm{NH}$. Abnormal maturation of cerebral cortex and behavioral deficits in adult rats after neonatal administration of antibody to ganglioside. Dev Brain Res 1981; 1: 25-35.

60. Kleinbeckel D. Acceleration of muscle reinnervation in rats by ganglioside treatment: an electromyographic study. Eur J Pharmacol 1983; 80: 243-245.

61. Kiedrowski L, Gradkowska M, Oderfeld-Nowak B. Time dependent effect of GM1 ganglioside administration on $\left.{ }^{3} \mathrm{H}\right] 5$-hydroxy-tryptamine uptake in partially denervated rat hippocampus. Neurochem Int 1987; 10: 191-198.

62. Kojima H, Gorio A, Janigro D, Jonsson G. GM1 ganglioside enhances regrowth of noradrenaline nerve terminals in rat cerebral cortex lesioned by the neurotoxin 6-hydroxydopamine. Neuroscience 1984; 13: 1011-1022.

63. Kromer LF. Nerve growth factor treatment after brain injury prevents neuronal death. Science 1987; 235: 214-216.

64. Lang W. Pharmacokinetic studies with $\left[{ }^{3} \mathrm{H}\right]$ labeled exogenous gangliosides injected intramuscularly into rats. In: Rapport MM, Gorio A, eds, Gangliosides in Neurological and Neuromuscular Function, Development and Repair. New York: Raven Press, 1981; 241-251.

65. Leeden RW. Ganglioside structure and distribution; are they localized at the nerve ending? $\mathrm{J}$ Supramolec Struct 1978; 8: 1-17.

66. Leeden RW. Biology of gangliosides: neuritogenic and neuronotrophic properties. J Neurosci Res 1984; $12: 147$.

67. Li YS, Mahadik SP, Rapport MM, Karpiak SE. Acute effects of GM1 ganglioside: Reduction in both behavioral asymmetry and loss of $\mathrm{Na}^{+}, \mathrm{K}^{+}$. ATPase after nigrostriatal transection. Brain Res 1986; 377: 292-297.

68. Lombardi G, Zanoni R, Moroni F. Systemic treatments with GM1 ganglioside reduce quinolinic acid-induced striatal lesions in the rat. Eur J Pharmacol 1989; 174: 123-125.

69. Mahadik SP, Vilim F, Korenovsky A, Karpiak SE. GM1 gangliosides protect nucleus basalis from 
excitotoxin damage: reduced cortical cholineric losses and animal mortality. J Neurosci Res 1988; 20: 479-483.

70. Marini P, Vitadello M, Bianchi R, Triban C, Gorio A. Impaired axonal transport of acetylcholinesterase in the sciatic nerve of alloxandiabetic rats: effect of ganglioside treatment. Diabetologia 1986; 29: 254-258.

71. Maysinger D, Garofalo L, Jalsenjak I, Cuello AC. Effects of microencapsulated monosialoganglioside GM1 on cholinergic neurons. Brain Res 1989; 496: 165-172.

72. Newsome DA, Dorsey FC, May JG, Bergsma DR, Bazan NG. Ganglioside administration in retinitis pigmentosa. J Ocul Pharmacol 1987; 3: 323-332.

73. Nicoletti F, Cavallaro B, Bruno V, Virgili M, Catania MV, Contestabile A, Canonico PL. Gangliosides attenuate NMDA receptor-mediated excitatory amino acid release in cultured cerebellar neurons. Neuropharmacology 1989; 28: 1283-1288.

74. Nieto-Sampedro M, Cotman CW. Growth factor induction and temporal order in CNS repair. In: Cotman CW, ed, Synaptic Plasticity. New York: Guilford Press, 1985; 407-455.

75. Nieto-Sampedro M, Lewis ER, Cotman CW, Manthorpe M, Skaper SD, Barbin G, Longo FM, Varon S. Brain injury causes a time-dependent increase in neuronotrophic activity at the lesion site. Science 1982; 217: 860-861.

76. Norido F, Canella $R$, Zanoni $R$, Gorio A. Development of diabetic neuropathy in the C57B1/Ks (db/db) mouse and its treatment with gangliosides. Exp Neurol 1984; 83: 221-232.

77. Oderfeld-Nowak B, Wojcik M, Ulas M, Potempska A. Effects of chronic ganglioside treatment on recovery processes in hippocampus after brain lesions in rats. In: Rapport $\mathrm{MM}$, Gorio A, eds, Gangliosides in Neuromuscular Function, Development and Repair. New York: Raven Press, 1981; 197-209.

78. Oderfeld-Nowak B, Jezierska M, Ulas J, Mitros K, Skup M. Enhancement by GM1 ganglioside treatment of acetylcholinesterase and choline acetyltransferase response in hippocampus following lesions of the entorhinal cortex. J Neurochem 1983; Suppl 41: 510.

79. Oderfeld-Nowak B, Skup M, Ulas J, Jezierska M, Gradkowska M, Zarenba $M$. Effect of GM1 ganglioside treatment on post-lesion responses of cholinergic enzymes in rat hippocampus after various partial deafferentations. J Neurosci Res 1984; 12: 409-420.

80. Oderfeld-Nowak B, Ulas J, Jezierska M, Skup M, Domanska-Janik K. Role of GM1 ganglioside in repair processes after hippocampal deafferentation in rats. In: Bignami $\mathrm{A}$, Bloom $\mathrm{FE}$, Bolis $\mathrm{CL}$, Adeloye A, eds, Central Nervous System Plasticity and Repair. New York: Raven Press, 1985; 85-96.

81. Orlando $P$, Cocciante $G$, Ippolito $G$, Masssari $P$, Roberti S, Tettamanti $G$. The fate of tritium labeled GM1 ganglioside injected in mice. Pharmacol Res Commun 1979; 11: 759-773.

82. Pedata F, Giovannelli L, Pepeu G. GM1 ganglioside facilitates the recovery of high-affinity choline uptake in the cerebral cortex of rats with a lesion of the nucleus basalis magnocellularis. J Neurosci Res 1984; 12: 421-427.

83. Pedata F, LoConte G, Sorbi S, Marconini-Pepeu I, Pepeu G. Changes in high affinity choline uptake in rat cortex following lesions of the magnocellular forebrain nuclei. Brain Res 1982; 233: 359-367.

84. Poplawsky A, Isaacson RL. The GM1 ganglioside hastens the reduction of hyperemotionality after septal lesions. Behav Neural Biol 1987; 48: 150-158.

85. Purpura DP, Baker HJ. Neurite induction in mature cortical neurones in feline GM1 ganglioside storage disease. Nature 1977; 266: 553-554.

86. Purpura DP, Suzuki K. Distortion of neuronal geometry and formation of aberrant synapses in neuronal storage disease. Brain Res 1976; 181: 1-21.

87. Quarles RH, Ilyas AA, Willison HJ. Antibodies to gangliosides and myelin proteins in Guillain-Barre syndrome. Ann Neurol 1990, 27: S48-52.

88. Raiteri M, Versace P, Marchi M. GM1 monosialoganglioside inner ester induces early recovery of striatal dopamine uptake in rats with unilateral nigrostriatal lesion. Eur J Pharmacol 1985; 118: 347-350.

89. Ramirez JJ, Fass B, Kilfoil T, Henschel B, Grones W, Karpiak SE. Ganglioside-induced enhancement of behavioral recovery after bilateral lesions of the entorhinal cortex. Brain Res 1987; 414: 85-90.

90. Roisen FJ, Bartfeld H, Nagel R, York G. Ganglioside stimulation of axonal sprouting in vitro. Science 1981; 214: 577-578.

91. Rosner H. Ganglioside changes in the chicken optic lobes as biochemical indicators of brain development and maturation. Brain Res 1982; 236: 49-61.

92. Sabel BA, Dunbar GL, Stein DG. Gangliosides minimize behavioral deficits and enhance structural repair after brain injury. J Neurosci Res 1984; 12: 429-443.

93. Sabel BA, Dunbar GL, Stein DG. GM1 ganglioside treatment facilitates behavioral recovery from bilateral brain damage. Science 1984; 225: 340-342.

94. Sabel BA, Dunbar GL, Butler WM, Stein DG. GM1 ganglioside stimulates neuronal reorganization and reduces rotational asymmetry after hemitransections of the nigro-striatal pathway. 
Exp Brain Res 1985; 60: 27-37.

95. Sabel BA, Dunbar GL, Fass B, Stein DG. Gangliosides, neuroplasticity, and behavioral recovery after brain damage. In: Will $B E$, Schmitt $P$, Dalrymple-Alford JC, eds, Brain Plasticity, Learning, and Memory. New York: Plenum Press, 1985; 481-493.

96. Sabel BA, Stein DG. Pharmacological treatment of central nervous system injury. Nature 1986; 323: 493.

97. Sabel BA, DelMastro R, Dunbar GL, Stein DG. Reduction of anterograde degeneration in brain damaged rats by GM1-yangliosides. Neurosci Lett 1987; 7: 360-366.

98. Sabel BA, Schneider GE. Enhanced sprouting of retinotectal fibers after early superior colliculus lesions in hamsters treated with gangliosides. Exp Brain Res 1988; 71: 365-376.

99. Savoini G, Fuxe K, Agnati LF, Calza L, Morani F, Lombardi MG, Goldstein M, Toffano G. Effect of GM1 ganglioside on recovery of dopaminergic nigro-striatal neurons after lesion. In: Bignami A, Bloom FE, Bolis CL, Adeloye A, eds, Central Nervous System Plasticity and Repair. New York: Raven Press, 1985; 75-85.

100. Sbaschnig-Agler M, Leeden RW, Grafstein B, Alpert RM. Ganglioside changes in the regenerating goldfish optic system: comparison with glycoproteins and phospholipids. J Neurosci Res 1984; 12: 221-232.

101. Schengrund C-L. The role(s) of gangliosides in neural differentiation and repair: a perspective. Brain Res Bull 1990; 24: 131-141.

102. Sebille A. Nerve regeneration in exogenous cerebral ganglioside-treated rats. Muscle Nerve 1984; 7: 278-280.

103. Skaper SD, Katoh-Semba R, Varon S. GM1 ganglioside accelerates neurite outgrowth from primary peripheral and central neurons under selective conditions. Dev Brain Res 1985; 23: 19-26.

104. Sofroniew MV, Pearson RCA, Cuello AC, Tagari PC, Stephens PH. Parenterally administeredd GM1 ganglioside prevents retrograde degeneration of cholinergic cells of the rat basal forebrain. Brain Res 1986; 398: 393-396.

105. Sparrow JR, McGuinness M, Schwartz M, Grafstein B. Antibodies to gangliosides inhibit goldfish optic nerve regeneration in vivo. J Neurosci Res 1984; 12: 233-243.

106. Spero DA, Roisen FJ. Ganglioside-mediated enhancement of the cytoskeletal organization and activity of neuro-2a neuroblastoma cells. Dev Brain Res 1984; 13: 37-48.

107. Stephens PH, Tagari PC, Garofalo L, Maysinger D, Piotte M, Cuello AC. Neural plasticity of basal forebrain cholinergic neurons: effects of gangliosides. Neurosci Lett 1987; 80: 80-84.

108. Spuler M, Dimpfel W, Tuller H-U. Ganglioside therapy in experimental neuropathy. Arzneimittelforschung 1988; 38: 881-884.

109. Stotzem CD, Mengs U, Odenthal KP. Influence of ganglioside treatment on acrylamide neuropathy in mice. Arzneimittelforschung 1988; 38: 1563-1567.

110. Svennerholm L, Fredman P. Antibody detection in Guillain Barre syndrome. Ann Neurol 1990; 27: S36-40.

111. Tettamanti G, Venerando B, Roberti S, Chigorno V, Sonnino S, Ghidoni R, Orlando P, Massari P. The fate of exogenously administered brain gangliosides. In: Rapport MM, Gorio A, eds, Gangliosides in Neurological and Neuromuscular Function, Development and Repair. New York: Raven Press, 1981; 225-270.

112. Toffano G, Benvegnu D, Bonetti AC, Facci L, Leon A, Orlando P, Ghidoni R, Tettamanti G. Interaction of GM1 ganglioside with crude rat brain neuronal membranes. J Neurochem 1980; 35: 861-866.

113. Toffano G, Savoini G, Moroni F, Lombardi G, Calza L, Agnati LF. GM1 ganglioside stimulates the regeneration of dopaminergic neurons in the central nervous system. Brain Res 1983; 261: 163166.

114. Toffano G, Agnati LF, Fuxe K, Aldinio C, Consolazione A, Valenti G, Savoini G. Effect of ganglioside treatment on the recovery of dopaminergic nigro-striatal neurons after different types of lesion. Acta Physiol Scand 1984; 122: 313321.

115. Toffano G, Savoini F, Aporti S, Calzolari A, Consolazione G, Maaura M, Marchi M, Raiteri M, Agnati LF. The functional recovery of damaged brain: the effect of GM1 monosialoganglioside. J Neurosci Res 1984; 12: 397-408.

116. Toffano G, Savoini GE, Moroni E, Lombardi G, Calza L, Agnati LF. Chronic GM1 ganglioside treatment reduces dopamine cell body degeneration in the substantia nigra after unilateral hemisection in rat. Brain Res 1984; 296: 233-239.

117. Vantini G, Fusco M, Bigon E, Leon A. GM1 ganglioside potentiates the effect of nerve growth factor in preventing vinblastine-induced sympathectomy in newborn rats. Brain Res 1988; 448: 252-258.

118. Walsh TJ, Emerich DF, Schmechel DE. GM1 ganglioside attenuates the behavioral deficits but not the granule cell damage produced in intradentate colchicine. Brain Res 1989; 478: 24-33.

119. Walsh TJ, Emerich DF, Bondy SC. Destruction of specific hippocampal cell fields increases ornithin decarboxylase activity: modulation of the 
biochemical but not the histological changes by ganglioside GM1. Exp Neurol 1989; 105: 54-61.

120. Walsh TJ, Emerich DF, Schmechel DE. GM1 ganglioside attenuates the behavioral deficits but not the granule cell damage produced by intradentate colchicine. Brain Res 1989; 478: 24-33.

121. Weihmuller FB, Hadjiconstantinou M, Bruno JP, Neff NH. Administration of GM1 ganglioside eliminates neuroleptic-induced sensorimotor deficits in MPTP-treated mice. Neurosci Lett 1988; 92: 207-212.

122. Williams LR, Varon S, Peterson GM, Wictorin K, Fischer W, Bjorklund A, Gage FH. Continuous infusion of nerve growth factor prevents basal forebrain neuronal death after fimbria fornix transection. Proc Natl Acad Sci USA 1986; 83: 9231-9235.

123. Willinger $\mathrm{M}$. The expression of GM1 ganglioside during neuronal differentiation. In: Rapport MM, Gorio A, eds, Gangliosides in Neurological and Neuromuscular Function, Development and Repair. New York: Plenum Press, 1981; 17-27.
124. Wojik M, Ulas J, Oderfeld-Nowak B. The stimulating effect of ganglioside injections in the recovery of choline acetyltransferase and acetylcholinesterase activities in the hippocampus of the rat after septal lesions. Neuroscience 1982; 7: 495499.

125. Wu G, Leeden RW. Stimulation of neurite outgrowth in neuroblastoma cells by neuraminidase: putative role of GM1 ganglioside in differentiation. J Neurochem 1991; 56: 95-104.

126. Yavin E, Gil S, Consolazione A, Dal Toso R, Leon A. Selective enhancement of tubulin gene expression and increase in oligo (dt)-bound RNA in the rat brain after nigrostriatal pathway unilateral lesion and treatment with ganglioside. J Neurosci Res 1987; 18: 615-620.

127. Yuki N, Yoshino H, Sato S, Miyatake T. Acute axonal polyneuropathy associated with anti-GM1 antibodies. Neurology 1990; 40: 1900-1902.

128. Zalutsky M, Magistretti P, Gallagher P, Ghidoni R. Radioiodinated ganglioside GM1: a potential tool for the investigation of ganglioside function in vivo. Pharmacol Res Commun 1985; 17: 897-912. 

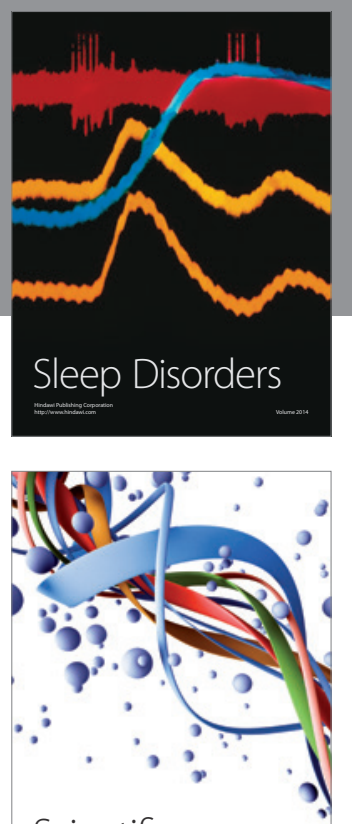

Scientifica
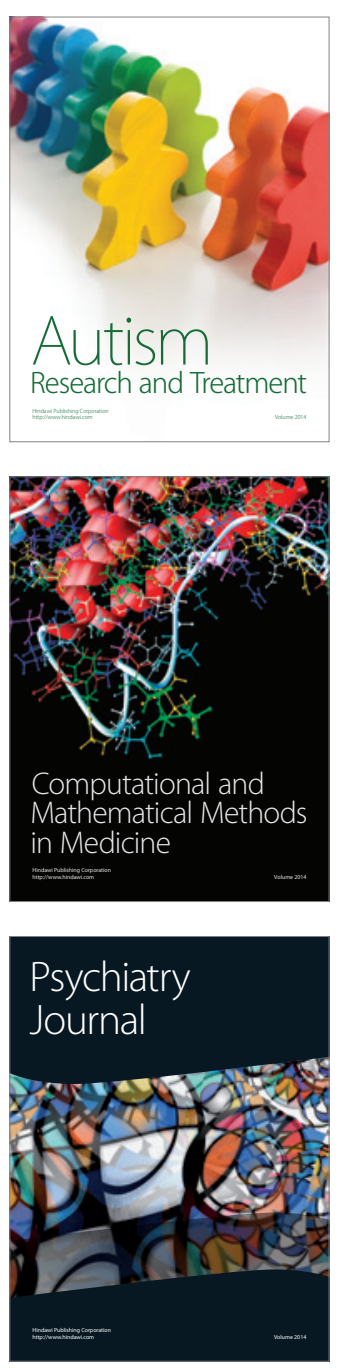
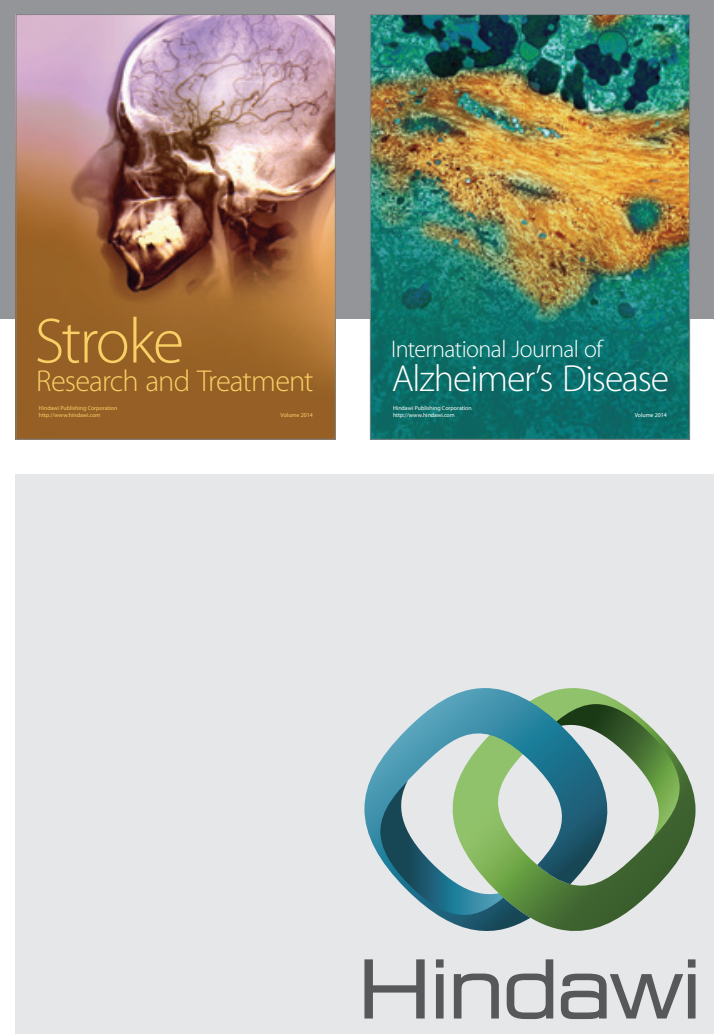

Submit your manuscripts at

http://www.hindawi.com
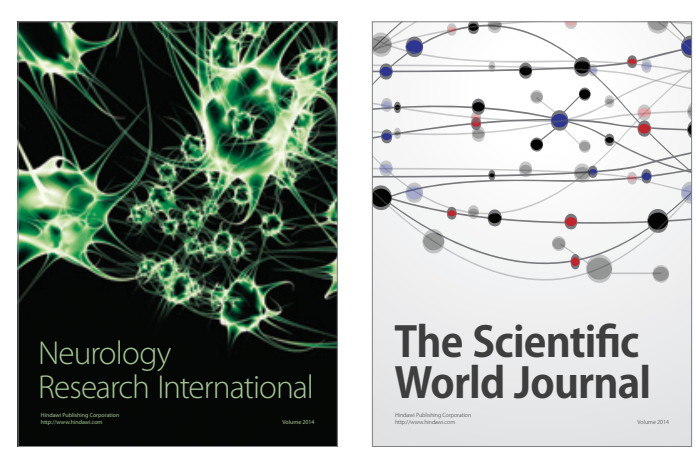

The Scientific World Journal

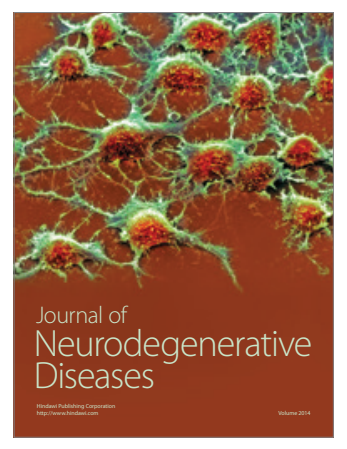

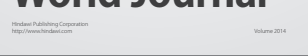

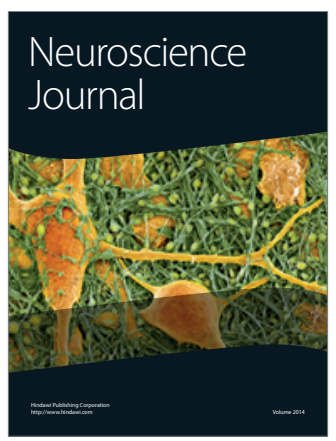

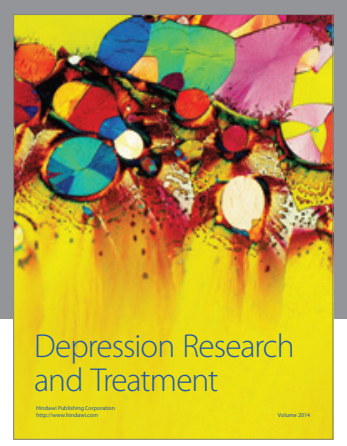
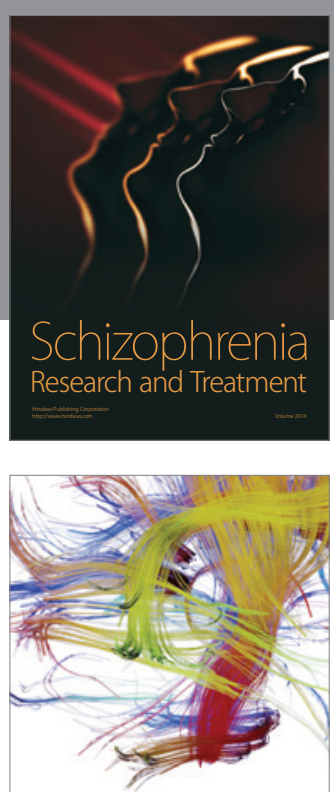

Brain Science

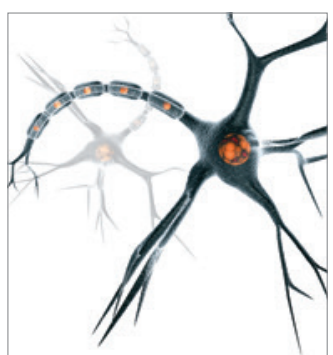

Neural Plasticity
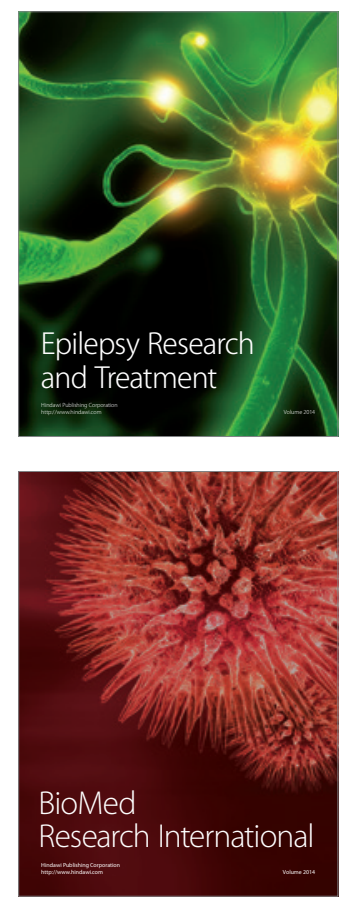

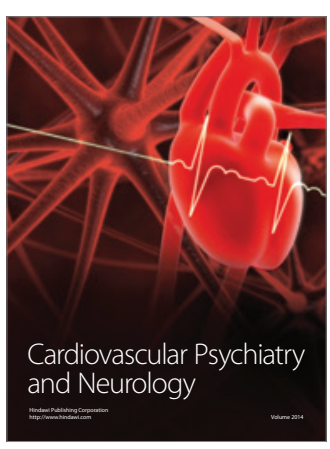

Parkinson's

Disease
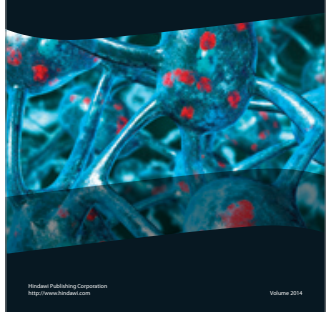